\title{
A biosensor platform based on amine functionalized conjugated benzenediamine-benzodithiophene polymer for testosterone analysis
}

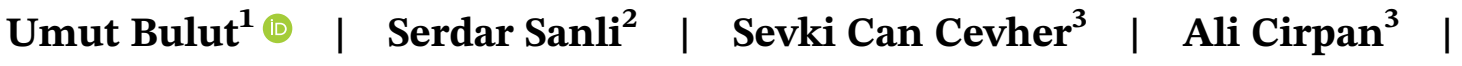 \\ Sude Donmez ${ }^{2}$ | Suna Timur ${ }^{2,4}$
}

\author{
${ }^{1}$ Faculty of Pharmacy, Analytical \\ Chemistry Department, Acibadem \\ Mehmet Ali Aydinlar University, İstanbul, \\ Turkey \\ ${ }^{2}$ Faculty of Science, Biochemistry \\ Department, Ege University, Izmir, \\ Turkey \\ ${ }^{3}$ Chemistry Department, Middle East \\ Technical University, Ankara, Turkey \\ ${ }^{4}$ Central Research Test and Analysis \\ Laboratory Application and Research \\ Center, Ege University, Izmir, Turkey

\section{Correspondence} \\ Umut Bulut, Faculty of Pharmacy, \\ Analytical Chemistry Department, \\ Acıbadem Mehmet Ali Aydinlar \\ University, 34752 Ataşehir, İstanbul, \\ Turkey. \\ Email: umut.bulut@acibadem.edu.tr \\ Funding information \\ Ege Üniversitesi, Grant/Award Number: \\ 18-EGEMATAL-001
}

\begin{abstract}
A novel benzenediamine-benzodithiophene polymer is synthesized for use in biosensor fabrication for the detection of testosterone. The sensory platform is constructed via drop coating on a screen-printed carbon electrode, using poly(benzenediamine-Bis[(2-ethylhexyl)oxy]benzodithiophene) (pBDBT) as the polymer layer. Testosterone antibodies are immobilized on the polymercoated electrode surface via glutaraldehyde, which binds to the surface through the amino functional groups on the polymer backbone. The changes in the surface features due to testosterone binding are investigated via electrochemical techniques such as differential pulse voltammetry, cyclic voltammetry, and electrochemical impedance spectrometry as well as contact angle measurements. Surface morphology of the modified electrodes is characterized by atomic force microscopy. The linear range and limit of detection of the sensor are calculated. Impact of possible interfering compounds is investigated. Furthermore, the sensory platform is utilized for testosterone analysis in synthetic biological fluids.
\end{abstract}

\section{KE Y W O D S}

applications, electrochemistry, sensors and actuators

\section{1 | INTRODUCTION}

Conducting polymers (CPs) have received great attention in a myriad of applications ranging from solar cells to organic light emitting diodes, tissue engineering to textile sector due to their paramount features that combine electrical properties of metals and mechanical properties of polymers. ${ }^{[1-8]}$ Electrical conductivity of conjugated polymers can be tuned from insulator to metallic while wide range of mechanical properties can be adjusted. ${ }^{[9-12]} \mathrm{CPs}$ possess both good electrical properties and the chemical tunability of polymers. ${ }^{[13]}$ Combining electrical properties and support/host abilities of conjugated polymers with highly specified sensing properties of antibodies pave the way of sensor technology of organic electronics. CP-based biosensors have very low limit of detection (LOD) values and enhanced sensitivity due to their unique optoelectronic properties. ${ }^{[14]}$ Suzuki $^{[15]}$ or Stille ${ }^{[16]}$ reactions are commonly employed for the synthesis of conjugated alternating copolymers. Alkyl and alkoxy side chains are introduced into CPs to improve solubility, redox activity, charge transporting capabilities, and optical absorption. ${ }^{[17-18]}$

Testosterone, the main androgen within skeletal muscle, has been abused for enhanced sport performance ${ }^{[19]}$ as it induces an increase in muscle mass. ${ }^{[20-21]}$ The World 
Anti-Doping Agency prohibited its use to ensure fair play and protect athletes from possible adverse side effects. ${ }^{[22]}$ Testosterone can also be found as contaminants in pharmaceuticals, waste materials, etc. Accordingly, there is a need for on-site detection and quantification of these molecules in different matrices. Several methods using biosensor applications are employed for the identification of testosterone, which have their own benefits and limitations. Conventional methods for testosterone analysis include radio-immunoassay, ${ }^{[23]}$ enzyme immunoassay, ${ }^{[24]}$ chromatographic methods such as HPLC, ${ }^{[25]} \mathrm{GC}-\mathrm{MS},{ }^{[26]}$ and LC-MS. ${ }^{[27]}$ However, these techniques are expensive and cannot be performed in situ. They have the disadvantage of complicated analytical procedures with tedious sample preparation. Electrochemical methods, on the other hand, provide fast, low cost, on-site analyses with high specificity and high sensitivity. Studies involving the use of electrochemical biosensors for determination of testosterone ${ }^{[28]}$ in biological fluids have also been reported as well as those for detection of other illicit drugs such as methamphetamine, ${ }^{[29]}$ dehydroepiandrosterone 3-sulfate, ${ }^{[30]}$ synthetic cannabinoids, ${ }^{[31]}$ and cocaine. ${ }^{[32]}$

Antibodies have been widely utilized in biosensors for detection of analytes. Generation of a signal due to the complex formed between antibody and antigen is monitored. Proper immobilization of antibody on the electrode surface is crucial in biosensor fabrication in terms of its performance and stability. Presence of robust covalent bonding chemical functionalities such as hydroxyl, amine, or carboxyl groups on conjugated polymers is a common tool to achieve successful antibody immobilization. ${ }^{[33-36]}$ Among them, amines have great impact on biosensor applications. Free amine functional groups enable the immobilization of antibodies onto polymeric surface via glutaraldehyde. Through covalent immobilization via crosslinking, strong and efficient bonding between the transducer surface (polymer coating in our case) and the biorecognition elements, such as enzymes and antibodies, results generally in increased lifetime and stability. ${ }^{[37]}$ Support matrices bearing amino groups through covalent bonding for immobilization of enzymes in biosensor fabrication $^{[38-39]}$ and bioconjugation with antibodies for targeted imaging studies ${ }^{[0]}$ have been reported. Hence, production of custom design polymers to be utilized for fabrication of any sort of biosensor is of particular interest.

This study presents the design and synthesis of a novel polymer, poly(benzenediaminebis[(2-ethylhexyl) oxy]-benzodithiophene) (pBDBT) via Stille coupling, and its use as a matrix in biosensor fabrication. Amino functional groups on the pBDBT polymer backbone served to immobilize anti-testosterone antibodies with glutaraldehyde. Polymer was drop-coated on disposable screen printed carbon electrodes (SPCE) for electrochemical measurements in order to afford a real-time, on-site detection platform. Step-wise modification of the electrode surface and the changes in electron transfer characteristics due to selective analyte binding was monitored by electrochemical techniques such as cyclic voltammetry (CV), differential pulse voltammetry (DPV), and electrochemical impedance spectroscopy (EIS). Surface morphologies were studied by atomic force microscopy (AFM). Furthermore, contact angles were measured. The performance of the proposed biosensor was finally tested on synthetic urine and serum samples spiked with testosterone.

\section{2 | RESULTS AND DISCUSSION}

\section{1 | Synthesis of poly(benzenediamine- bis[(2-ethylhexyl)oxy]benzodithiophene)}

Benzodithiophene (BDT), with its fused structure, possesses high thermal stability with high conductivity when incorporated into CPs. ${ }^{[41]}$ Chemical modification of alkoxysubstituted BDT fused core improves the processability of the conjugated polymer. In addition, the ease of synthesis of the core amine functionalized benzene moiety was primarily beneficial for facilitating the production of biosensor as amino functional groups incorporated to the pBDBT polymer backbone served to immobilize anti-testosterone antibodies. Presence of branched alkoxy groups on BDT units was essential for improving the solubility of the copolymer.

Polymerization of functionalized monomers was a common strategy to have amino side groups on the conjugated backbone of the resulting polymer. ${ }^{[42]}$ Accordingly, conjugated polymer was synthesized by a common methodology of Stille polycondensation technique with 3,6-dibromobenzene-1,2-diamine and a commercially available BDT derivatives in the presence of a palladium catalyst. The synthetic pathway for the synthesis of pBDBT was depicted in Scheme 1.

\section{2 | Biosensor fabrication and analytical characteristics}

The use of SPCEs is advantageous since miniaturization of electrodes leads to reduction of sample amount, lower cost, portability, ease of surface modification, and SPCEs can be easily adapted to on-site analysis. For the construction of the sensor, $\mathrm{p}(\mathrm{BDBT})$ dissolved in dichloromethane was drop-coated on an SPCE. Anti-testosterone antibodies were immobilized on the polymer chains via glutaraldehyde. The schematic representation of surface modification was illustrated in Scheme 2. 
Modification of the electrode surfaces was verified by DPV and CV. Current responses of polymer-coated electrode and antibody-immobilized electrode before and after capturing testosterone in the presence of redox probe were analyzed. DPV peak current values of bare SPCE, SPCE/pBDBT, SPCE/pBDBT/antibody $\left(\mathrm{Ab}_{\mathrm{TES}}\right)$, and SPCE/pBDBT/Ab $\mathrm{ABS}_{\mathrm{TES}} /$ testosterone (TES) were 297, 115, 198, and $183 \mu \mathrm{A}$, respectively (Figure 1a). An abrupt decrease in peak current value was observed as polymer was coated on bare SPCE surface, possibly arising from increased thickness of diffusion layers on the electroactive surface. Peak current values increase consequent to immobilization of antibodies. It was not surprising because it would be due to the availability of positively charged groups on the biomolecule that attracts negatively charged redox probe. On the other hand, binding of testosterone to the proposed surface causes a drop that was related to the analyte concentration.

Step-by-step surface modification and analyte binding (interaction with testosterone) monitored by $\mathrm{CV}$ are given in Figure 1b. Decrease in anodic and cathodic<smiles>c1ccc2nsnc2c1</smiles>

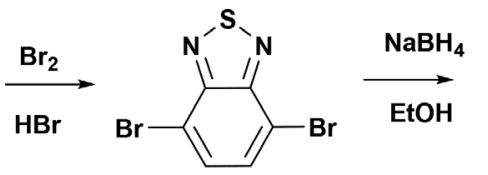<smiles>Nc1c(Br)ccc(Br)c1N</smiles><smiles>Nc1c(Br)ccc(Br)c1N</smiles><smiles></smiles><smiles></smiles>

SCHEME 1 Synthetic pathway of polymer
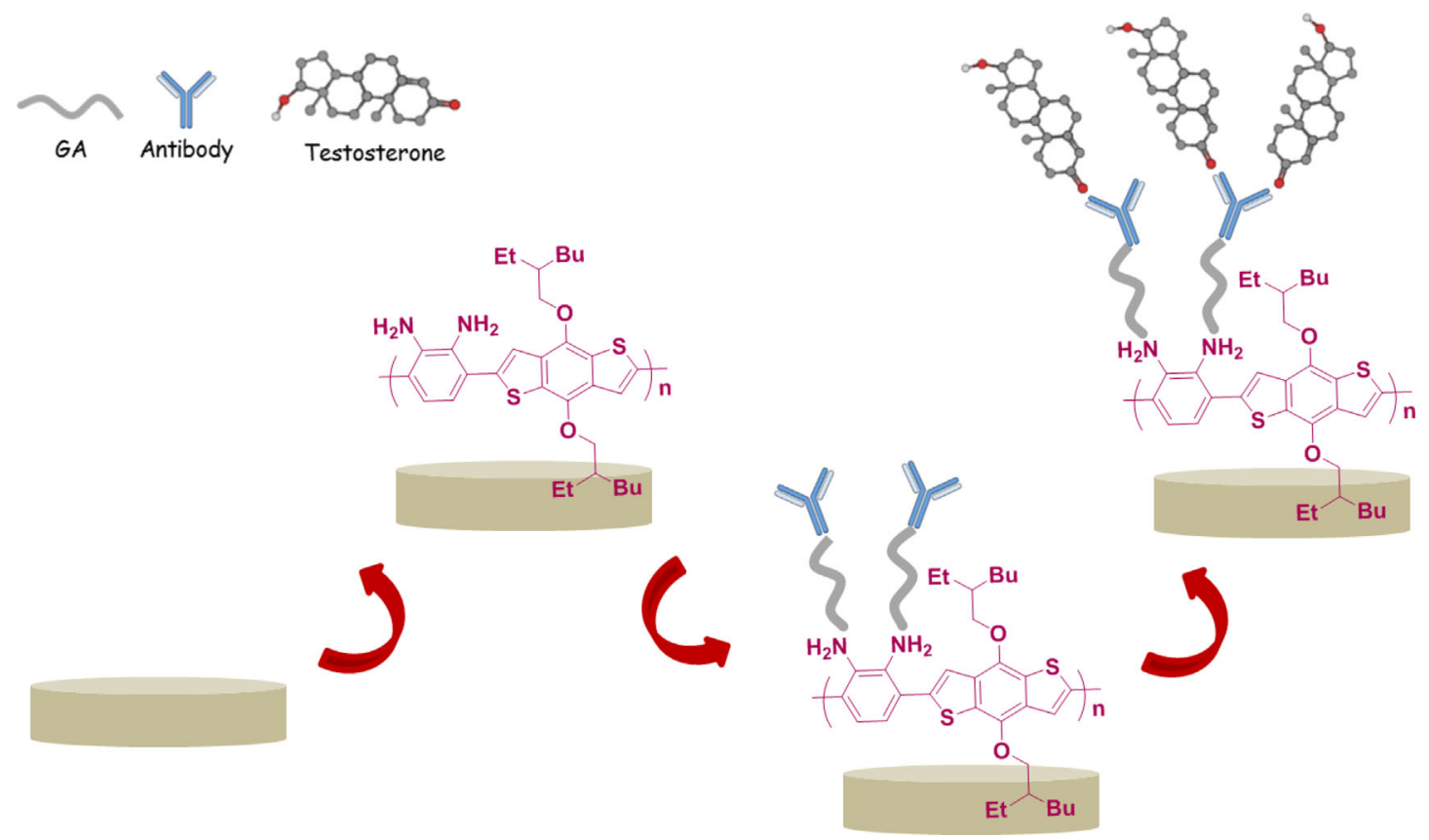

SCHEME 2 Illustration of the step-by-step surface modification of the sensor [Color figure can be viewed at wileyonlinelibrary.com] 


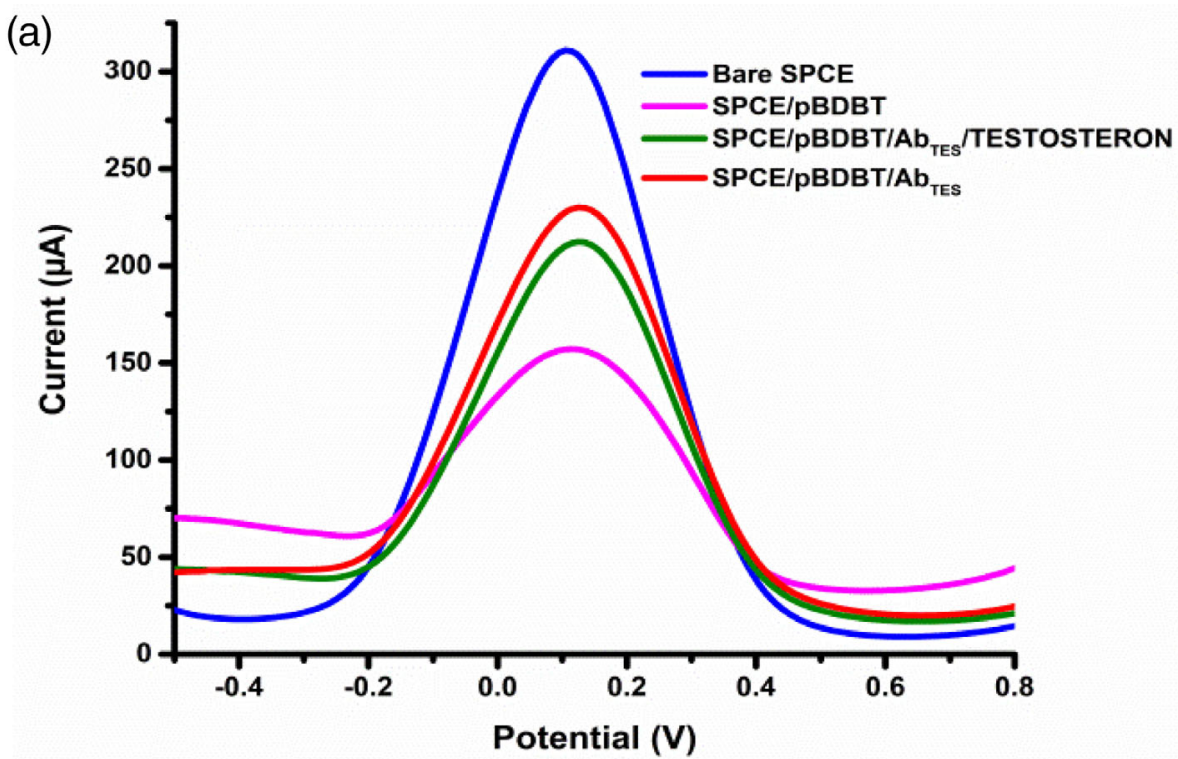

F I G URE 1 (a) DPV and (b) CV diagrams of bare SPCE, SPCE/pBDBT, $\mathrm{SPCE} / \mathrm{pBDBT} / \mathrm{Ab}_{\mathrm{TES}}$, and SPCE/ $\mathrm{pBDBT} / \mathrm{Ab}_{\mathrm{TES}} / \mathrm{TES}$. (50 mM sodium phosphate buffer, $\mathrm{pH} 7.4$, in the presence of $5.0 \mathrm{mM}\left[\mathrm{Fe}(\mathrm{CN})_{6}\right]^{3-/ 4-}$ and $0.1 \mathrm{M} \mathrm{KCl}$ ) [Color figure can be viewed at wileyonlinelibrary.com]

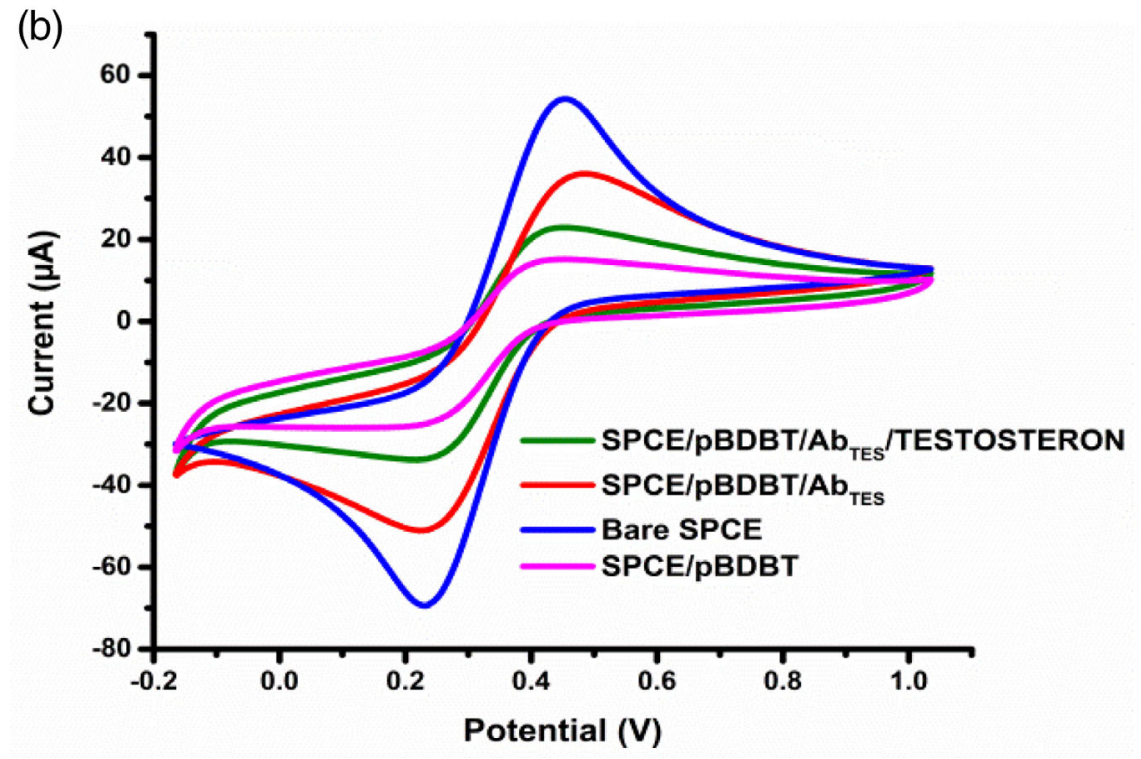

current peaks was observed. The anodic and cathodic peak currents were obtained as 66.88 and $-71.81 \mu \mathrm{A}$ (peak-to-peak separation of $0.218 \mathrm{~V}$ ) for bare SPCE, 17.81 and $-24.09 \mu \mathrm{A}$ (peak-to-peak separation of $0.204 \mathrm{~V}$ ) for SPCE/pBDBT, 42.46 and $-50.93 \mu \mathrm{A}$ (peak-to-peak separation of 0.24 ) for $\mathrm{SPCE} / \mathrm{pBDBT} / \mathrm{Ab}_{\mathrm{TES}}$ and 26.43 and $-33.1 \mu \mathrm{A}$ (peak-to-peak separation of $0.21 \mathrm{~V}$ ) for SPCE/ $\mathrm{pBDBT} / \mathrm{Ab}_{\mathrm{TES}} /$ testosterone surfaces. Values reveal that electron transfer between electrolytes and electrodes was impeded as a result of surface coating.

A calibration curve based on analyte concentration versus changes in current values upon surface modification was plotted using the difference in response signals due to reduction of $\mathrm{Fe}^{\mathrm{III}} / \mathrm{Fe}^{\mathrm{II}}$ species obtained from the differential pulse voltammograms. Linearity was observed in the range of 10 to $500 \mathrm{ng} / \mathrm{ml}$ and defined by the equation of $y=0.1055 x+5.9272$ where $R^{2}$ equals 0.9936 , showing a good linear range for the sensing system.

Other analytical parameters such as LOD and repeatability for SPCE/pBDBT/ $/ \mathrm{Ab}_{\mathrm{TES}}$ surface were investigated. The repeatability was confirmed with 10 successive measurements. Values of standard deviation and coefficient of variation were calculated as 0.433 and $1.25 \%$, respectively. LOD was obtained as $16.72 \mathrm{ng} / \mathrm{ml}$ for testosterone analysis by using $3 S D / \mathrm{m}$ formulation ( $S D$ : standard deviation of the minimum value). In Table 1 , analytical performance data of the proposed sensor was summarized. Analytical performances of previously reported sensing platforms for testosterone analysis are presented in 
Table 2. Among them, our proposed sensor has a wide linear range and a convenient LOD for testosterone detection in various media.

Further indication for the confirmation of surface modification was provided by EIS. Data were fitted according to the circuit design containing solution resistance $\left(\mathrm{R}_{\mathrm{s}}\right)$, Warburg impedance $\left(\mathrm{Z}_{\mathrm{w}}\right)$ due to the diffusion of the $\left[\mathrm{Fe}(\mathrm{CN})_{6}\right]^{3-/ 4-}$ redox probe, the double layer capacitance $\left(\mathrm{C}_{\mathrm{dl}}\right)$ and the charge transfer resistance $\left(\mathrm{R}_{\mathrm{ct}}\right)$, shown in the inset of Figure 2. The $R_{\mathrm{ct}}$ values of Nyquist plots of the biosensor were $1,284 \Omega$ for bare SPCE, $8,784 \Omega$ for SPCE/pBDBT, $1,963 \Omega$ for SPCE/pBDBT/ $\mathrm{Ab}_{\mathrm{TES}}$, and 3,591 $\Omega$ for SPCE/pBDBT/Ab $\mathrm{T}_{\mathrm{TES}} / \mathrm{TES}$. Surface modifications resulting in changes in electron transfer properties can be deduced from these variations in $\mathrm{R}_{\mathrm{ct}}$ values.

Selectivity of the biosensor was investigated with various interferences such as ascorbic acid, lactic acid, dehydroepiandrosterone (DHEA), and cholesterol. Concentration of testosterone and all interferants was $100 \mathrm{ng} / \mathrm{ml}$. Figure 3 demonstrates that the proposed biosensor was highly selective to testosterone when compared to the other compounds that can be found in biological matrices and could be present together with testosterone.

T A B LE 1 Some analytical features of the designed sensor platform

\begin{tabular}{|ll|}
\hline Linear range in logarithmic scale $(\mathbf{n g} / \mathbf{m l})$ & $\mathbf{1 0 - 5 0 0}$ \\
\hline Limit of detection $(\mathrm{ng} / \mathrm{ml})$ & 16.72 \\
\hline Repeatability $( \pm S D)$ & 0.433 \\
\hline Coefficient of variation $(\%)$ & 1.25 \\
\hline
\end{tabular}

The biosensor was also tested for the analysis of synthetic biological fluids, such as urine and serum, spiked with known amounts of testosterone (100 and $250 \mathrm{ng} / \mathrm{ml}$ ). Each measurement was repeated six times and corresponding testosterone concentration values were compared with the known concentrations. Values of percentage recovery for synthetic urine and synthetic serum were $103.4 \pm 1.0 \%$ and $98.0 \pm 5.3 \%(100 \mathrm{ng} / \mathrm{ml}$ testosterone); and $113.8 \pm 1.1 \%$ and $105.6 \pm 2.2 \%$ $(250 \mathrm{ng} / \mathrm{ml}$ testosterone), respectively, where percent relative standard deviation (\%RSD) values for $250 \mathrm{ng} / \mathrm{ml}$ testosterone solutions were found as $1.1 \%$ in synthetic urine and $2.2 \%$ in synthetic serum. These results indicate that the biosensor was highly efficient for the detection of testosterone in biological fluids.

\section{3 | Surface characterization}

Surface morphologies were investigated by AFM. Noncontact mode AFM images of polymer films were obtained and values of average roughness were measured as $16.8 \mathrm{~nm}$ for bare SPCE, $19.8 \mathrm{~nm}$ for SPCE/ pBDBT surface; $21.7 \mathrm{~nm}$ for SPCE/pBDBT/Ab $/ b_{\mathrm{TES}}$ surface; $20.1 \mathrm{~nm}$ for SPCE/pBDBT/Ab ${ }_{\mathrm{TES}}$ after testosterone addition (Figure 4). AFM results confirm surface modifications since changes in surface roughness were observed.

The contact angles were measured to observe surface properties and determined as $70.09^{\circ}$ for bare electrode, $89.77^{\circ}$ for polymer coated electrode, $33.73^{\circ}$ for polymer/ antibody coated electrode, and $90.44^{\circ}$ for polymer $/ \mathrm{Ab}_{\mathrm{TES}} /$ TES coated electrode. These values were in agreement with the hydrophobic nature of the polymer and

TA B LE 2 Comparison of miscellaneous sensing platforms for testosterone analysis

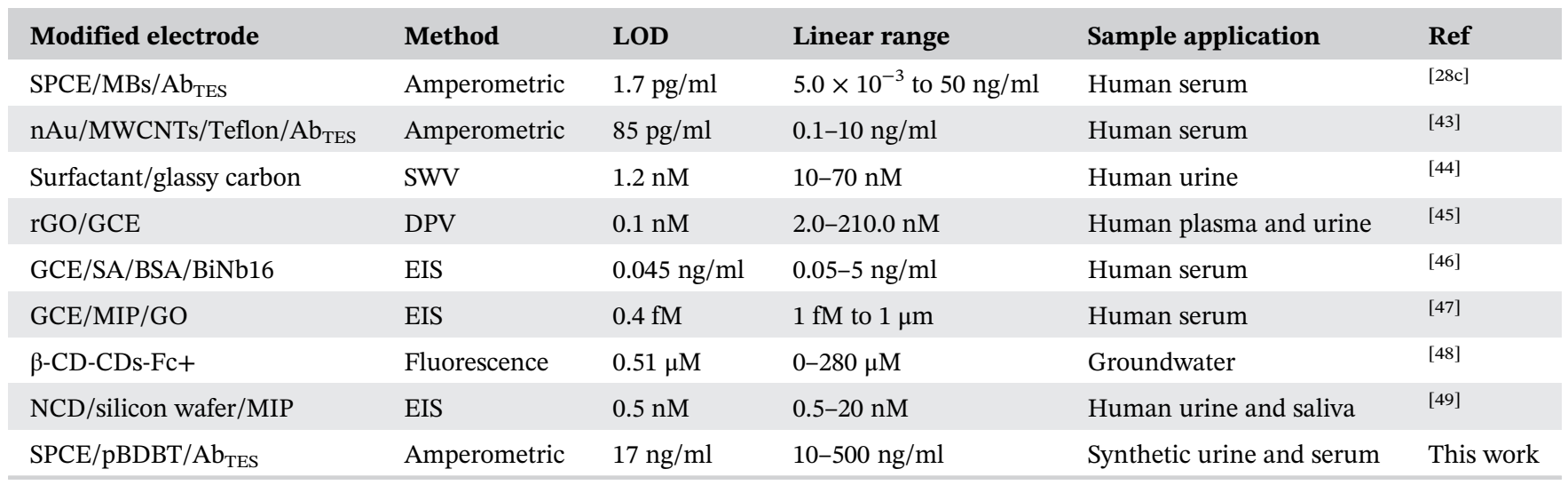

Abbreviations: BiNb, biotinylated nanobody; BSA, bovine serum albumin; DPV, differential pulse voltammetry; EIS, electrochemical impedance spectroscopy; MBs, protein A-functionalized magnetic beads; MIP, molecularly imprinted polymer; MWCNTs, multiwalled carbon nanotubes; nAu, gold nanoparticles; GCE, glassy carbon electrode; NCD, nano-crystalline diamond; rGO, reduced graphene oxide; GO, graphene oxide; SA, streptavidin; SWNT, single-wall carbon nanotubes; SWV, square wave voltammetry. 


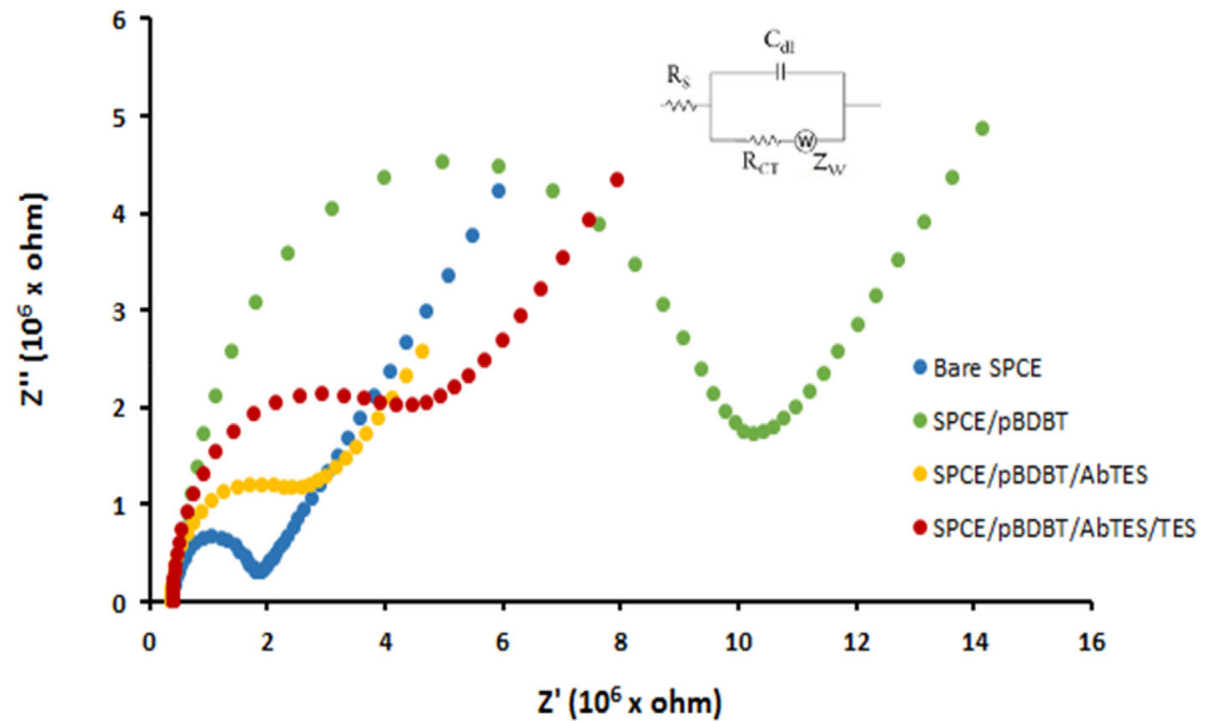

F I G U RE 2 Nyquist diagrams of the modified electrode surfaces (Nyquist plots were fitted according to Randle's equivalent circuit which was shown in inset). Measurements were carried out in $50 \mathrm{mM}$ sodium phosphate buffer $(\mathrm{pH} 7.0)$ containing $5.0 \mathrm{mM}\left[\mathrm{Fe}(\mathrm{CN})_{6}\right]^{3-/ 4-}$ and $0.1 \mathrm{M} \mathrm{KCl}$ [Color figure can be viewed at wileyonlinelibrary.com]

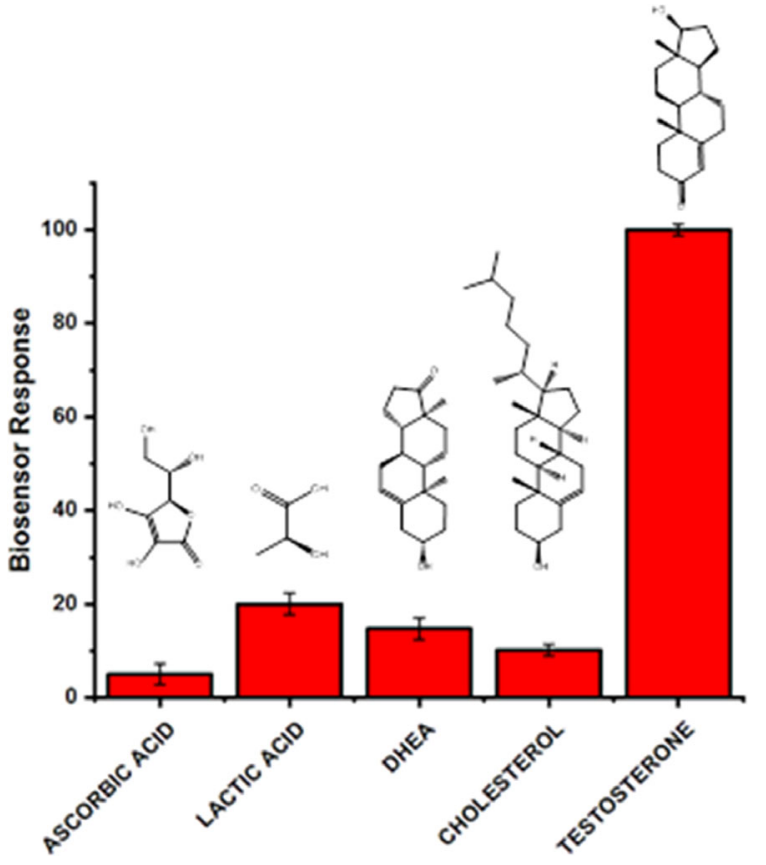

F I G U RE 3 Influence of interferants such as ascorbic acid, lactic acid, dehydroepiandrosterone (DHEA), and cholesterol. Error bars show $\pm S D$ [Color figure can be viewed at wileyonlinelibrary.com]

testosterone. An increase in the contact angle was observed due to the increase in hydrophobicity of the surface with the coating of the polymer and decrease with the immobilization of the antibodies as expected. It decreases with capturing of testosterone, which was a hydrophobic molecule. Accordingly, it was concluded that modification of the electrode surface with the polymer, antibody, and testosterone altered the contact angle.

\section{CONCLUSIONS}

In this study, our strategy was to design a polymer which can be coated onto different substrates with various sizes as well as geometries to afford a functional surface ready for one-step biomolecule immobilization or oriented biomolecule binding in mild conditions depending on the desired properties for a biosensor. The newly designed polymer was found to be a good candidate as a biosensor for the detection of testosterone abuse. The analytical performance of $\mathrm{SPCE} / \mathrm{pBDBT} / \mathrm{Ab}_{\mathrm{TES}}$ was excellent with its linear range between 10 and $500 \mathrm{ng} / \mathrm{ml}$ for detection of testosterone. Biosensor does not display a significant response when other possible interference compounds were applied, and can be used for testosterone analysis in biological fluid samples.

Testosterone was chosen as a model compound among performance-enhancing substances. This assembly with pBDBT is anticipated to be useful for the detection of other doping substances as well, and will be studied. It can be an effective detection system as a sensor for the illegal drugs via their corresponding biological recognition compounds.

\section{4 | EXPERIMENTAL SECTION}

\section{1 | Materials and reagents}

4,8-Bis((2-ethylhexyl)oxy)benzo[1,2-b:4,5- $\left.b^{\prime}\right]$ dithiophene2,6-diyl)-bis(trimethylstannane) was purchased from Lumtec. 2,1,3-Benzothiadiazole was purchased from Sigma-Aldrich. Tetrahydrofuran (THF) was used as freshly distilled over $\mathrm{Na}$ /Benzophenone under nitrogen 
(a)

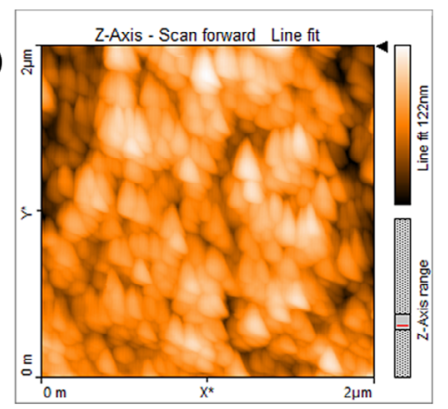

(b)

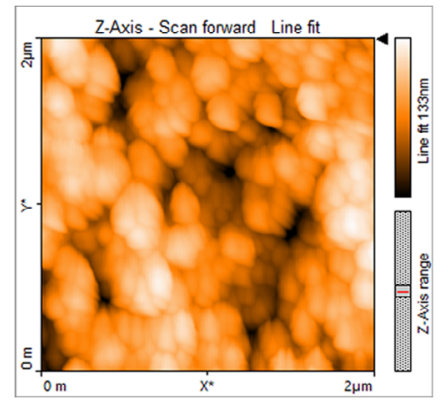

(c)

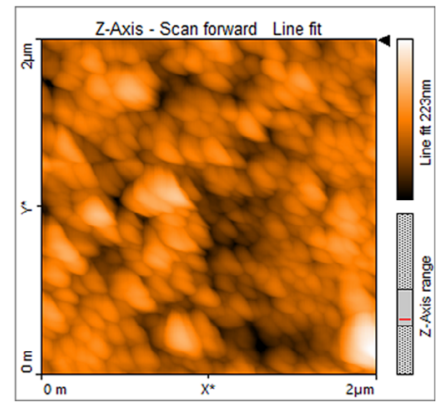

(d)

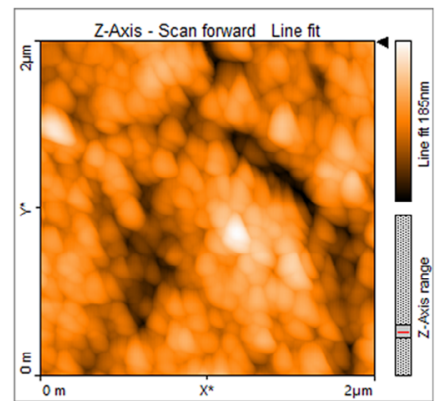

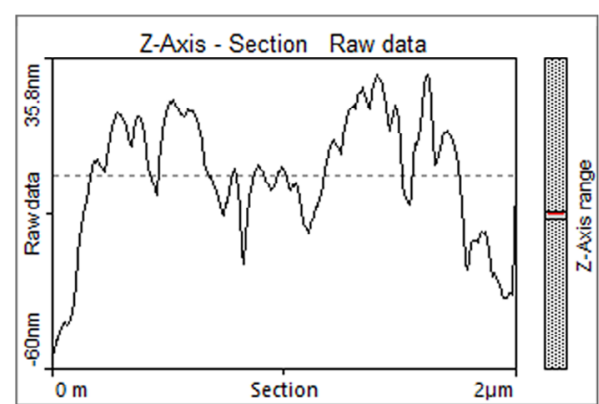
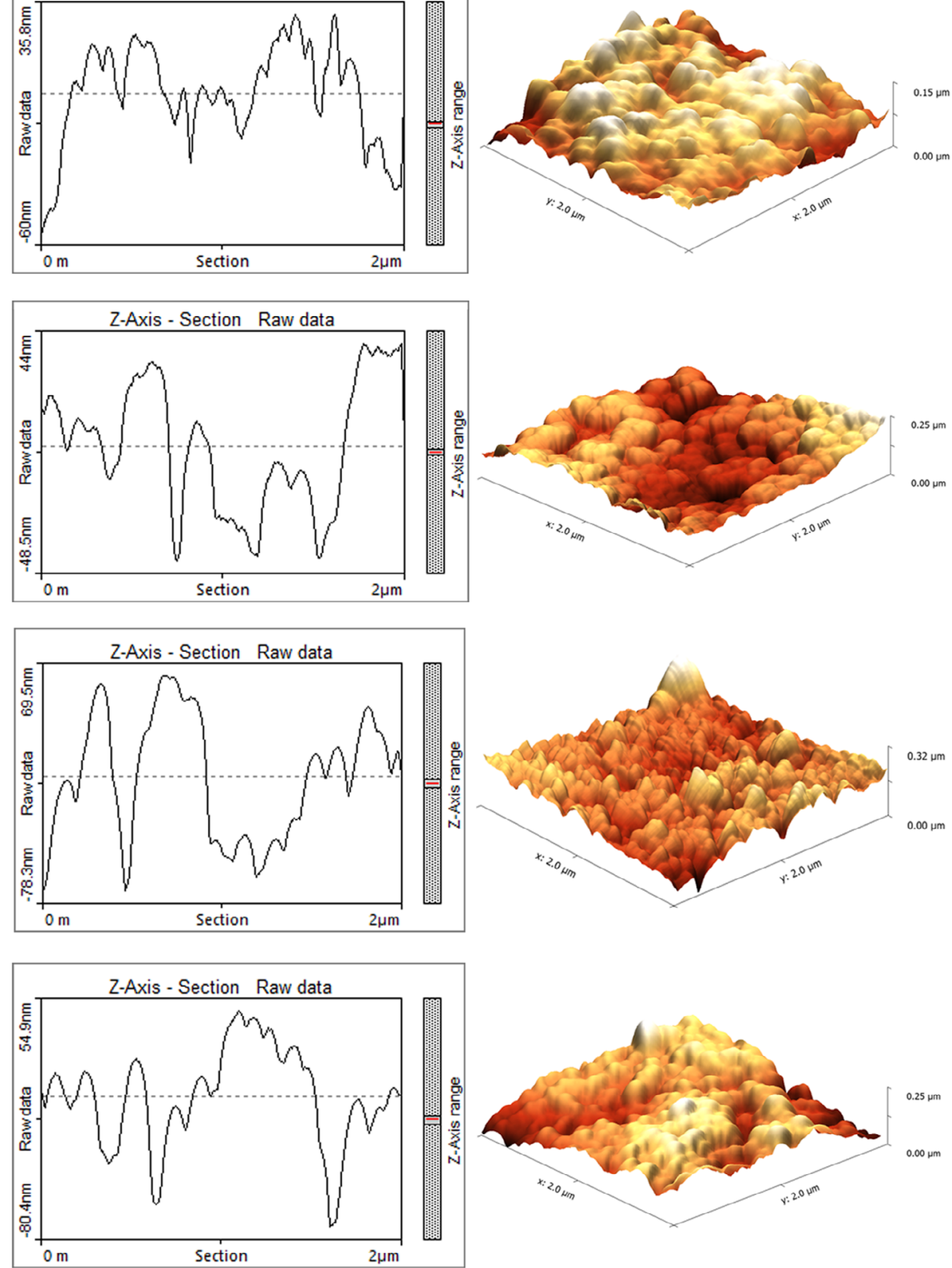

F I G U RE 4 3D AFM topographic images and section analysis with height images of (a) bare SPCE, (b) SPCE/pBDBT, (c) SPCE/pBDBT/ $\mathrm{Ab}_{\mathrm{TES}}$, and (d) SPCE/pBDBT/Ab $\mathrm{T}_{\mathrm{TES}} / \mathrm{TES}$ [Color figure can be viewed at wileyonlinelibrary.com]

atmosphere. Cysteamine hydrochloride, glutaraldehyde solution (Grade II, 25\%), testosterone, Dehydroepiandrosterone 3-sulfate sodium salt solution, Dehydroepiandrosterone solution, cholesterol, BSA (lyophilized powder, $96 \%$ [agarose gel electrophoresis]), potassium chloride, lactic acid, ascorbic acid, uric acid, glutaraldehyde (GA, 25\%), potassium hexacyanoferrate (III) $[\mathrm{K} 3 \mathrm{Fe}(\mathrm{CN}) 6]$ (as redox probe), and other chemical reagents were purchased from Sigma Chemical Company (St. Louis, MO). Synthetic urine $^{[50]}$ and serum ${ }^{[51]}$ samples were prepared according to the previous works.

\subsection{1 | Synthesis procedure of 3,6-dibromobenzene-1,2-diamine}

3,6-Dibromobenzene-1,2-diamine is synthesized according to literature ${ }^{[52]}$ : Bromination of benzothiadiazole is 
achieved under reflux with $\mathrm{HBr}$ and molecular bromine. After cooling the reaction mixture to room temperature, $\mathrm{NaHSO}_{3}$ is added slowly. Filtering the solids yields a light yellow product which is washed with diethyl ether several times and final solid 4,7-dibromobenzo[c][1,2,5] thiadiazole is used without further purification. 4,7Dibromobenzo[c] $[1,2,5]$ thiadiazole is reacted with $\mathrm{NaBH}_{4}$ in ethanol overnight and then ethanol is removed under reflux and extraction is done with diethyl ether/water mixture. Organic layer is collected and dried over $\mathrm{Na}_{2} \mathrm{SO}_{4}$ and solvent is removed under reduced pressure and product 3,6-dibromobenzene-1,2-diamine is obtained as white solid. ${ }^{1} \mathrm{H}$ and ${ }^{13} \mathrm{C}$ NMR spectra are run in $\mathrm{CDCl}_{3}$ and trimethylsilane (TMS) used as the internal reference. ${ }^{1} \mathrm{H}$ NMR $\left(400 \mathrm{MHz}, \mathrm{CDCl}_{3}\right)$ \&: 6.77 (s, 2H), 3.75 (broad s, 4H). ${ }^{13} \mathrm{C}$ NMR (101 MHz, $\left.\mathrm{CDCl}_{3}\right)$ 8: 133.74, 123.27, 109.70. Synthetic pathway of monomer and polymer can be seen in Scheme 1.

\subsection{2 | Synthesis procedure of poly(benzenediamine-bis[(2-ethylhexyl) oxy]benzodithiophene)}

$100 \mathrm{mg}, 0.376 \mathrm{mmol}$ of 3,6-dibromobenzene-1,2-diamine and $290 \mathrm{mg} 0.376 \mathrm{mmol}$ of 4,8 -Bis((2-ethylhexyl)oxy) benzo[1,2-b:4,5- $\left.b^{\prime}\right]$ dithiophene-2,6-diyl)Bis

(trimethylstannane) were dissolved in freshly distilled THF and bubbled for 25 min under nitrogen atmosphere. Then, $5.0 \%$ mole $\mathrm{Pd}\left(\mathrm{PPh}_{3}\right)_{2} \mathrm{Cl}_{2}$ was introduced to reaction medium and temperature was set to reflux for $72 \mathrm{hr}$. At the end of this period, 2-bromothiophene was added and reacted for $3 \mathrm{hr}$ and then 2-stanyllatedthiophene was added and reacted overnight. After the reaction mixture was cooled to room temperature, solvent was evaporated under reduced pressure and polymer was dissolved in minimum amount of chloroform and precipitated in methanol. Polymer solids were collected by filtration, and purification was done by using Soxhlet extraction using methanol hexane dichloromethane and chloroform, respectively. Polymers were collected in two different portions in dichloromethane and chloroform. Solvents of these portions were evaporated under reduced pressure and precipitated in methanol. Gel permeation chromatography was carried out with respect to polystyrene standards in $\mathrm{CHCl}_{3}$ solvent. Polymers collected in dichloromethane portion $(70 \mathrm{mg}$, $\mathrm{M}_{\mathrm{n}}=3.9 \mathrm{kDa}, \mathrm{M}_{\mathrm{w}}=6.4 \mathrm{kDa}$, PDI $=1.6$ ), and in chloroform portion $\left(100 \mathrm{mg}, \mathrm{M}_{\mathrm{n}}=6.2 \mathrm{kDa}, \mathrm{M}_{\mathrm{w}}=9.8 \mathrm{kDa}\right.$, PDI $=1.6)$ were collected as brown solid. ${ }^{1} \mathrm{H}$ NMR spectrum was run in $\mathrm{CDCl}_{3}$ and TMS used as the internal reference. ${ }^{1} \mathrm{H}$ NMR $\left(400 \mathrm{MHz}, \mathrm{CDCl}_{3}\right)$ \&: $7.6-7.45 \mathrm{ppm}$ aromatic (benzodithiophene), $7.1-6.95 \mathrm{ppm}$ aromatic (benzene), 4.3-3.9 ppm aliphatic $-\mathrm{OCH}_{2}$ and $-\mathrm{NH}_{2}$,
1.85-1.70 ppm aliphatic $-\mathrm{CH}, 1.7-1.2 \mathrm{ppm}$ aliphatic $-\mathrm{CH}_{2}, 1.00-0.80$ ppm aliphatic $-\mathrm{CH}_{3}$.

\section{2 | Instrumentation}

For polymer characterization, ${ }^{1} \mathrm{H}$ and ${ }^{13} \mathrm{C}$ NMR spectra were run on a Bruker Spectrospin Avance DPX-400 Spectrometer. Gel permeation chromatography was performed by using Shimadzu instrument RID20A detector.

DPV and CV measurements were carried out with PalmSensPotentiostat (Palm Instruments, Houten, the Netherlands). EIS was performed with A CHI 6005C electrochemical analyzer $(\mathrm{CH}$ Instruments Incorporation, Austin, TX). SPCE's (Metrohm DropSens, Asturias, Spain) were utilized in electrochemical measurements. All experiments were performed at ambient conditions.

Morphologies of the unmodified and modified surfaces were investigated by AFM by Nanosurf model Easyscan 2 Flex AFM (Switzerland). Area roughness and sizes were obtained with Nanosurf Easyscan 2 software version 3.4.0.8., Gwyddion software version 2.39, from 2D and 3D AFM images $\left(2 \times 2 \mu \mathrm{m}^{2}\right.$ scan size $)$. Contact angles were determined after each modification using Attension Theta Contact Tensiometer and One Attension Version 2.6 (r5305) software.

\section{3 | Biosensor construction}

A $4.0 \mu \mathrm{l}$ of pBDBT solution $(1.0 \mathrm{mg} / \mathrm{ml})$ dissolved in dichloromethane was drop coated on the working electrode of SPCE and allowed to dry at room temperature. A $2.0 \mu \mathrm{l} \% 0.01$ glutaraldehyde was put on the polymer coated surface followed by the addition of $2.0 \mu \mathrm{l}$ antitestosterone antibody $(0.5 \mathrm{mg} / \mathrm{ml}$ in $10 \mathrm{mM}, \mathrm{pH} 7.4$, sodium phosphate buffer), and allowed to dry at ambient conditions. Five microliters of testosterone solutions with different concentrations were applied on the biosensor surface.

\section{4 | Electrochemical measurements}

Electrochemical measurements were performed on SPCEs. Response signals of bare, polymer coated, antibody immobilized, and testosterone treated electrodes were collected using a water soluble redox probe $(5.0 \mathrm{mM}$ $\left[\mathrm{Fe}(\mathrm{CN})_{6}\right]^{3-/ 4-}$ in $\left.0.1 \mathrm{M} \mathrm{KCl}\right)$ via $\mathrm{DPV}$ with a potential range of -0.4 to $+0.8 \mathrm{~V}$. A calibration graph was plotted for varying analyte concentrations. CV measurements were carried out in the potential range of -0.8 to $0.7 \mathrm{~V}$, in the presence of $5.0 \mathrm{mM}\left[\mathrm{Fe}(\mathrm{CN})_{6}\right]^{3-/ 4-}$ in $1.0 \mathrm{mM} \mathrm{KCl}$. 
EIS measurements were performed in sodium phosphate buffer $(50 \mathrm{mM}, \mathrm{pH} 7.4)$ in the presence of $5.0 \mathrm{mM}$ $\left[\mathrm{Fe}(\mathrm{CN})_{6}\right]^{3-/ 4-}$ in $0.1 \mathrm{M} \mathrm{KCl}$. The frequency range of EIS measurements were 0.017 to $1,000 \mathrm{~Hz}$ at $0.18 \mathrm{~V}$.

\section{5 | Sample application}

$\mathrm{SPCE} / \mathrm{pBDBT} / \mathrm{Ab}_{\mathrm{TES}}$ biosensor was utilized for the detection of testosterone in synthetic urine and synthetic serum. A calibration curve by using testosterone $(10,25$, $50,75,100$, and $200 \mathrm{ng} / \mathrm{ml}$ ) was plotted. Each measurement was performed in six replicates. Data were recorded as the mean $\pm S D$. Measurements were carried out at ambient conditions $\left(25^{\circ} \mathrm{C}\right)$.

\section{ACKNOWLEDGMENT}

This study was supported by Ege University, Scientific Research Project Coordination (BAP) as 18EGEMATAL-001.

\section{ORCID}

Umut Bulut (10) https://orcid.org/0000-0002-4282-5233

\section{REFERENCES}

[1] R. Balint, N. J. Cassidy, S. H. Cartmell, Acta Biomater. 2014, 10 (6), 2341.

[2] A. M. Bryan, L. M. Santino, Y. Lu, S. Acharya, J. M. D'Arcy, Chem. Mater. 2016, 28(17), 5989.

[3] I. Nuramdhani, M. Jose, P. Samyn, P. Adriaensens, B. Malengier, W. Deferme, G. De Mey, L. Van Langenhove, Polymers (Basel) 2019, 11(2), 345.

[4] P. Li, D. Du, L. Guo, Y. Guo, J. Ouyang, J. Mater. Chem. C 2016, 4(27), 6525.

[5] B. Guo, P. X. Ma, Biomacromolecules 2018, 19(6), 1764.

[6] T. K. Das, S. Prusty, Polymer Plast. Technol. Eng. 2012, 51(14), 1487.

[7] M. Tomczykowa, M. Plonska-Brzezinska, Polymers (Basel) 2019, 11(2), 350.

[8] R. Gracia, D. Mecerreyes, Polymer Chem. 2013, 4(7), 2206.

[9] A. J. Epstein, Electrical conductivity in conjugated polymers. in Conductive Polymers and Plastics, Vol. 2 (Ed: L. Rupprecht), Elsevier, Norwich, NY 1999, p. 1.

[10] D. T. Scholes, P. Y. Yee, G. R. McKeown, S. Li, H. Kang, J. R. Lindemuth, X. Xia, S. C. King, D. S. Seferos, S. H. Tolbert, B. J. Schwartz, Chem. Mater. 2019, 31(1), 73.

[11] G. Zotti, G. Schiavon, S. Zecchin, J.-F. Morin, M. Leclerc, Macromolecules 2002, 35(6), 2122.

[12] S. Savagatrup, A. S. Makaram, D. J. Burke, D. J. Lipomi, Adv. Funct. Mater. 2014, 24(8), 1169.

[13] T. H. Le, Y. Kim, H. Yoon, Polymers, 2017, 9(4), 150.

[14] a) Q. Zhou, T. M. Swager, J. Am. Chem. Soc. 1995, 117(50), 12593. b) G. Inzelt, Electroanalysis and biosensors. in Conducting Polymers - A New Era in Electrochemistry (Ed: F. Scholz), Springer, Berlin Heidelberg 2008, p. 241.
[15] a) J. Sakamoto, M. Rehahn, G. Wegner, A. D. Schlüter, Macromol. Rapid Commun. 2009, 30(9-10), 653. b) A. Suzuki, Angew. Chem. 2011, 50(30), 6722.

[16] a) B. Carsten, F. He, H. J. Son, T. Xu, L. Yu, Chem. Rev. 2011, 111(3), 1493. b) E. Negishi, Angew. Chem. 2011, 50(30), 6738.

[17] A. Pron, P. Rannou, Progress in Polymer Science 2002, 27 (1), 135.

[18] S. J. Higgins, Chem. Soc. Rev. 1997, 26(4), 247.

[19] J. Shelley, H. J. Moir, A. Petróczi, The use and misuse of testosterone in sport. in Nutrition and Enhanced Sports Performance, Elsevier, London, United Kingdom 2019, p. 571.

[20] S. Bhasin, L. Woodhouse, and T. W. Storer, Growth Horm. IGF Res., 2003, 13(Supplement), S63.

[21] F. Hartgens, H. Kuipers, Sports Medicine 2004, 34(8), 513.

[22] C. J. Houtman, S. S. Sterk, M. P. M. van de Heijning, A. Brouwer, R. W. Stephany, B. van der Burg, E. Sonneveld, Anal. Chim. Acta 2009, 637(1-2), 247.

[23] C. Ankarberg-Lindgren, E. Norjavaara, Scand. J. Clin. Lab. Inv. 2015, 75, 341.

[24] M. Sarkar, B. K. Dutta Borah, H. H. D. Meyer, B. S. Prakash, Gen. Comp. Endocrinol. 2008, 158, 240.

[25] X. F. Li, M. Ma, A. Cheng, J. Zheng, Y. K. Tam, Anal. Chim. Acta 2002, 457, 165.

[26] C. Saudan, N. Baume, P. Mangin, M. Saugy, J. Chromatogr. B 2004, 810, 157.

[27] A. Leinonen, T. Kuuranne, T. Kotiaho, R. Kostiainen, Steroids 2004, 69, 101.

[28] a) H. Lu, M. P. Kreuzer, K. Takkinen, G. G. Guilbault, Biosens. Bioelectron. 2007, 22, 1756. b) K.-Z. Liang, J.-S. Qi, W.-J. Mu, Z.-G. Chen, J. Biochem. Biophys. Methods 2008, 70, 1156. c) M. Eguílaz, M. Moreno-Guzmán, S. Campuzano, A. GonzálezCortés, P. Yáñez-Sedeño, J. M. Pingarrón, Biosens. Bioelectron. 2010, 26, 517.

[29] B. Demir, T. Yilmaz, E. Guler, Z. P. Gumus, H. Akbulut, E. Aldemir, H. Coskunol, D. G. Colak, I. Cianga, S. Yamada, S. Timur, T. Endo, Y. Yagci, Talanta 2016, 161, 789.

[30] S. Balaban, C. Durmus, E. Aydindogan, Z. P. Gumus, S. Timur, Electroanalysis 2019, 31, 1.

[31] T. Y. Sengel, E. G. Celik, C. Aydogan, Z. P. Gumus, R. Ilktac, E. Aydindogan, M. Ciftci, E. Aldemir, H. Coskunol, S. Timur, ChemElectroChem 2018, 5, 1253.

[32] a) E. Guler, G. Bozokalfa, B. Demir, Z. P. Gumus, B. Guler, E. Aldemir, S. Timur, H. Coskunol, Drug Test. Anal. 2017, 9, 578. b) T. Y. Sengel, E. Guler, M. Arslan, Z. P. Gumus, S. Sanli, E. Aldemir, H. Akbulut, D. Odaci Demirkol, H. Coskunol, S. Timur, Y. Yagci, Mater. Sci. Eng. C 2018, 90, 211.

[33] K. Lee, K. Kim, H. Yoon, H. Kim, Polymers (Basel) 2018, 10 (5), 551.

[34] M. Kesik, O. Kocer, F. E. Kanik, N. A. Unlu, E. Rende, E. Aslan-Gurel, R. M. Rossi, Y. A. Udum, L. Toppare, Electroanalysis 2013, 25(8), 1995.

[35] S. Soylemez, T. Yilmaz, E. Buber, Y. A. Udum, S. Özçubukçu, L. Toppare, J. Mater. Chem. B 2017, 5(35), 7384.

[36] M. Kesik, H. Akbulut, S. Söylemez, Ş. C. Cevher, G. Hizalan, Y. Arslan Udum, T. Endo, S. Yamada, A. Çirpan, Y. Yagci, L. Toppare, Polym. Chem. 2014, 5(21), 6295.

[37] R. Ford, S. J. Quinn, R. D. O'Neill, Sensors (Switzerland) 2016, 16(10), 1565. 
[38] E. Guler, H. Akbulut, G. Bozokalfa, B. Demir, G. Oyman Eyrilmez, M. Yavuz, D. Odaci Demirkol, H. Coskunol, T. Endo, S. Yamada, S. Timur, Y. Yagci, Macromol. Chem. Phys. 2015, 216, 1868.

[39] H. Akbulut, G. Bozokalfa, D. N. Asker, B. Demir, E. Guler, D. Odaci Demirkol, S. Timur, Y. Yagci, ACS Appl. Mater. Interfaces 2015, 7, 20612.

[40] C. Geyik, E. Guler, Z. P. Gumus, F. B. Barlas, H. Akbulut, D. Odaci Demirkol, S. Timur, Y. Yagci, Macromol. Biosci. 2017, 17(3), 1600232.

[41] L. Wang, C. Pan, Z. Chen, X. Zhou, C. Gao, L. Wang, Polym. Chem. 2018, 9(35), 4440.

[42] W. Schuhmann, R. Lammert, B. Uhe, H. L. Schmidt, Sens. Actuators B: Chem. 1990, 1, 537.

[43] V. Serafin, M. Eguilaz, L. Agui, P. Yanez-Sedeno, J. M. Pingarron, Electroanalysis 2011, 23(1), 169.

[44] A. Levent, A. Altun, Y. Yardım, Z. Sentürk, Electrochim. Acta 2014, 128, 54.

[45] R. Heidarimoghadam, O. Akhavan, E. Ghaderi, E. Hashemi, S. S. Mortazavi, and A. Farmany, Mater. Sci. Eng. C, 2016, 61, 246.

[46] G. Li, M. Zhu, L. Ma, J. Yan, X. Lu, Y. Shen, Y. Wan, ACS Appl. Mater. Interfaces 2016, 8, 13830.
[47] W. Liu, Y. Ma, G. Sun, S. Wang, J. Deng, H. Wei, Biosens. Bioelectron. 2017, 92, 305.

[48] M. Luo, Y. Hua, Y. Liang, J. Han, D. Liu, W. Zhao, P. Wang, Biosens. Bioelectron. 2017, 98, 195.

[49] E. Kellens, H. Bove, T. Vandenryt, J. Lambrichts, J. Dekens, S. Drijkoningen, J. D'Haen, W. Ceuninck, R. Thoelen, T. Junkers, K. Haenen, A. Ethirajan, Biosens. Bioelectron. 2018, 118, 58.

[50] J. A. Wilsenach, C. A. Schuurbiers, and. M. C. Van Loosdrecht, Water Res., 2007, 41, 458.

[51] E. B. Bahadır, M. K. Sezgintürk, Artif. Cells Nanomed. Biotechnol. 2014, 44(2), 462.

[52] D. J. Hong, E. Lee, H. Jeong, J.-K. Lee, W.-C. Zin, T. D. Nguyen, S. C. Glotzer, M. Lee, Angew. Chem. Int. Edit. 2009, 48(9), 1664.

How to cite this article: Bulut $U$, Sanli S, Cevher SC, Cirpan A, Donmez S, Timur S. A biosensor platform based on amine functionalized conjugated benzenediamine-benzodithiophene polymer for testosterone analysis. J Appl Polym Sci. 2020;137:e49332. https://doi.org/10.1002/app.49332 